\title{
Obtainment, quantification and use of lactulose as a functional food - a review
}

\author{
Fernanda Caspers ZIMMER ${ }^{1}$, Aline Kirie GOHARA ${ }^{2}$, Aloisio Henrique Pereira de SOUZA ${ }^{3}$, \\ Makoto MATSUSHITA², Nilson Evelázio de SOUZA², Angela Claudia RODRIGUES ${ }^{1 \star}$
}

\begin{abstract}
Whey (milk serum) is produced by the dairy industry during the manufacture of cheese. In addition to being a valuable source of functional and nutritional proteins, whey also presents almost all the lactose from the original whole milk. However, many industries still consider the whey as an effluent, which can cause serious environmental problems when not properly treated. Therefore, it is important to develop alternatives for the adequate use of whey. The lactose obtained from whey permeate can be converted into lactulose, a prebiotic which may be metabolized in the intestine by probiotic bacteria, such as Lactobacillus sp. and Bifidobacterium sp., through enzymatic isomerization or by using alkaline catalysts, with minimal secondary reactions and high yield. This manuscript provides information about various techniques used to produce lactulose, its purification and analysis, as well as its mechanisms of action and alternative applications in food products and medicines.
\end{abstract}

Keywords: lactose isomerization; lactulose; prebiotics; reuse of industrial byproducts; whey permeate.

Practical Application: Synthesizing and quantifying lactulose from whey permeate, and use in the dairy industry.

\section{Introduction}

Lactulose (4-O-ß-D-galactopyranosyl-D-fructose) is a disaccharide consisting of galactose and fructose (Figure 1) that was first synthesized as a new sugar in 1930 (Montgomery \& Hudson, 1930; Tamura et al., 1993). It is obtained from lactose, has about half the sweetness of sucrose and shows $76.4 \%$ solubility in water at $30^{\circ} \mathrm{C}$ (Modler et al., 1990; Gänzle et al., 2008).

However, its prebiotic effect was not noted until 1957 (Montgomery \& Hudson, 1930; Tamura et al., 1993). Subsequent evidence for its efficacy as a prebiotic in vivo has increased the use of lactulose in dairy products (Philippi, 2008), endowing functionality to foods in which it is used. Among its various nutritional and pharmacological properties, lactulose has low caloric content and low cariogenicity, and it is capable of preventing adhesion and pathogenicity of bacteria and toxins. Besides, lactulose can be used by food industries to enrich products due to its prebiotic benefits for human health (Aider \& Halleux, 2007; Gänzle et al., 2008).

Prebiotics are fermentable, non-digestible oligosaccharides that increase the activity and number of some bacteria in the intestine, thus, promote the host health (Olano \& Corzo, 2009; Nath et al., 2016). Dietary fibers and non-digestible oligosaccharides are the major growth substrates of the microorganisms in the intestine. According to Roberfroid (2002), the most effective prebiotics decrease the activity of potentially pathogenic organisms. Some effects attributed to prebiotics are the modulation of important physiological functions, such as the immune system, calcium absorption, lipid metabolism, they can change the microbiota from intestine and reduce the production of some carcinogenic agents, produce anti-tumorigenic compounds, change the activities of the microbiota metabolism in the intestine, and change some physicochemical characteristics of colon, which play a key role in intestinal physiology, and the colon cancer risk reduction (Roberfroid, 2002; Olano \& Corzo, 2009).

Thus, due to its prebiotic potential, lactulose is not absorbed nor metabolized in the small intestine, being available for bacteria in the large intestine, metabolized by several microorganisms, including bifidobacteria and lactobacilli. This oligosaccharide isprimarily used as a food supplement due to the health benefits derived from the increase in the colonic populations of these endogenous probiotic microorganisms (Tamura et al., 1993; Silva \& Stamford, 2000). There are many studies about the benefits provided by the application of lactulose in food products, such as positive changes in intestinal microbiota, regulation of intestine acting, increasing of calcium absortion. Technologically, when used in the production of fermented milk, lactulose may stimulate good microorganisms growing, reducing incubaton time, and the production of different oligosaccharides with complementary advantages to lactulose (Olano \& Corzo, 2009).

There is a growing demand for products with specific functional properties in the meat industry. Therefore, the use of prebiotics from whey is promising because the whey can be incorporated in the formulation of meat products, such as hams, by substituting the water (Botega et al., 2009). According to Okara et al. (2010), the enrichment of meat products by adding 


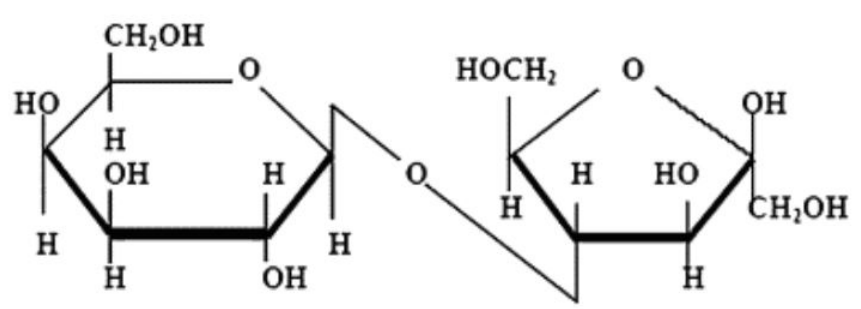

Figure 1. Molecular structure of lactulose $\left(\mathrm{C}_{12} \mathrm{H}_{22} \mathrm{O}_{11} ; 4-\mathrm{O}-\mathrm{b}-\mathrm{D}\right.$ galactopyranosyl-b-D-fructofuranose) (Seki \& Saito, 2012).

lactulose is an innovation requested by consumers due to the potential positive effects for health and disease prevention. The addition of lactulose could also improve some technological properties, such as color and emulsifying capacity. Restructured meat products, such as ham, are often considered less healthy products because of their fat content, additives and spices. In this sense, the addition of prebiotics to these foods may afford health benefits related to lactic acid bacteria and contribute to increasing the consumption of those products (Erkkila et al., 1999).

Although the process for obtaining lactulose in its pure form is somewhat complex, the "syrup", rich in lactulose, can be obtained in a relatively simple way and it is more easily found from a commercial perspective. However, these syrups contain further constituents, particularly carbohydrates (galactose, lactose and sugars), which can modify the product texture due to their binding properties (Zhang et al., 2010). Ramos \& Gomide (2007) highlight the importance of texture as a quality attribute in evaluating restructured products, contributing to the product sensory quality, determining its acceptability and consumer satisfaction.

\subsection{Whey}

Bovine whey, which provides lactose to lactulose synthesis, is a byproduct of cheese production. For a long time, its main destination was animal feeding, or even the direct disposal as effluent (Yorgun et al., 2008), causing serious environmental impacts because of its high biochemical oxygen demand, resulting in one of the biggest dairy industry concerns.

Whey pollutes a hundred times more than domestic sewage. Therefore, action is essential to reuse this waste, such as the optimization of processes in the dairy industry and the reuse of whey for product manufacturing.

Conversely, bovine whey has aroused the interest of many researchers worldwide due to its nutritional, functional and economical potential. The whey, a greenish-yellow liquid, contains $55 \%$ of the solids of full cream milk, and a high quantity of lactose, minerals and water-soluble vitamins. It is about $80-90 \%$ of the volume used in the manufacturing of cheese (Andrade \& Martins, 2002; Atra et al., 2005).

The lactose concentration in milk varies widely among species and is also affected by the breed, individuality factor and, above all, the stage of lactation (Fox \& McSweeney, 1998). The presence of lactose in milk is important because it is the main energy source for microorganism development. Particularly, lactose is the most abundant component in dried dairy products, reaching
$70 \%$ in powdered whey (Fox \& McSweeney, 1998). Despite being the most abundant solid in whey, it has not a large application in food products due to its low sweetness and solubility (Pelegrine \& Carrasqueira, 2008; Oliveira, 2009; Ziegler \& Sgarbieri, 2009). However, it does find use as a value-added ingredient in several food products, such as meat, bread, pastries, snacks and drinks, particularly since evidence of its functional and bioactive properties (Pelegrine \& Carrasqueira, 2008).

The proteins from whey are the most valuable substances in this by-product, and some industries are reusing them through a pre-concentration process using ultrafiltration. Ultrafiltration is a membrane separation operation performed to concentrate or fractionate the liquid, resulting in two solutions of different composition. It is based on selective permeation defined by components molecules size. The whey (process feeding) is separated into two products: the fluid that crosses the membrane (filtrate or permeate); and the one that remains with the process feeding (concentrate), known as the retentate, which contains solutes or suspended solids that were rejected by the membrane (Ordoñez, 2005).

The commercial use of membrane technology, including ultrafiltration, diafiltration and ion exchange, has enabled the development of many products with diverse and great functionalities (Fennema et al., 2010). Ultrafiltration allows a variation in the concentration relation of whey components (Baldasso et al., 2011).

As noted by Ordoñez (2005), the industry where the membrane separation operations are more entrenched is the dairy industry, because it allows processing and reutilizing two by-products generated in large quantity: the whey from cheese production and the skimmed milk. The first one used to be discarded, despite the contamination it causes; while the second one was used for animal feed or for milk powder.

After the ultrafiltration, the retentate, which has the whey protein, is spray-dried to produce the whey protein concentrate powder. This is a continuous process where the liquid or paste is transformed into a dry product. It is characterized by a relatively short drying time, and the process basically consists of the liquid atomization in a compartment that receives warm air flow. This process is very fast and does not cause significant changes in the product (Yee et al., 2007).

The process of reusing the bovine whey to produce the whey protein concentrate powder generates another by-product, the whey permeate. This permeate presents great amounts of lactose, but spray drying process is unviable due to the low price of this component. Also, part of the product is lost due to its caking process during storage, which results from crystallization of the amorphous lactose (Pereira et al., 2010; Perrone et al., 2011). An alternative reuse of the dry whey permeate is to isomerize the lactose to lactulose, increasing its commercial value.

\section{Lactulose production}

Some processes can be applied in the production of lactulose to obtain greater yields of the disaccharide amount synthesized from lactose. These processes may be the isomerization of lactose in alkaline medium by Lobry de Bruyn-Alberda van Ekenstein reaction (Figure 2), rearranging the glucose residue into the 


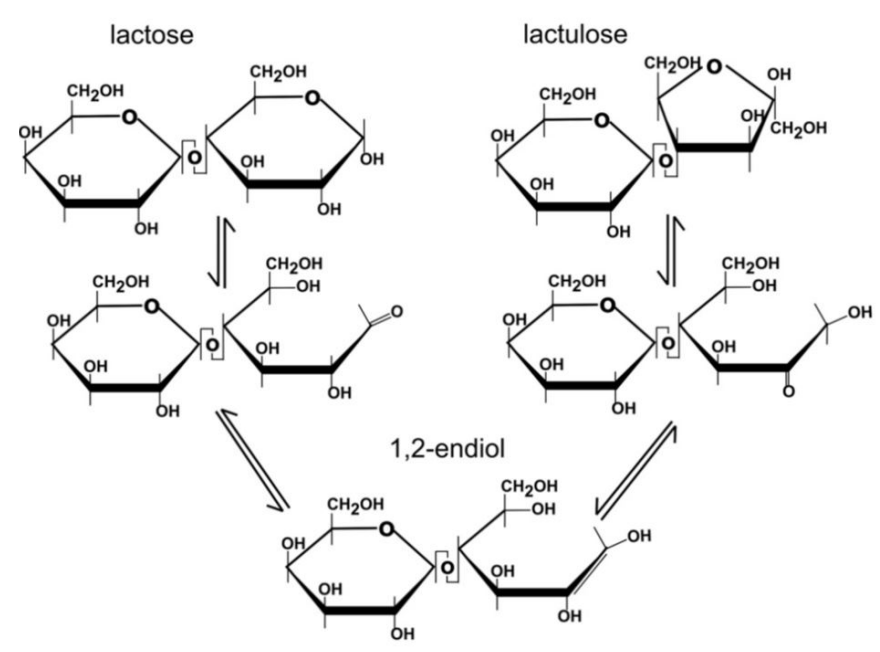

Figure 2. Lobry de Bruyn e Alberda van Ekenstein rearrangement of lactose (Schuster-Wolff-Bühring et al., 2010).

fructose molecule, or by enzymatic catalytic synthesis. There are many kinds of processes that involve the production of this compound (Schuster-Wolff-Bühring et al., 2010).

However, care must be taken in the extraction and purification of lactulose, since a large number of complexing reagents such as alumiates and borates, alkalis like sodium and calcium hydroxides, or $\beta$-galactosidase enzymes used in the transgalactosylation reaction can catalyze the isomerization of lactose in lactulose. Thus, the catalyst must have some properties such as low cost, easy to remove from medium, safe and non-toxic (Aider \& Halleux, 2007; Schuster-Wolff-Bühring et al., 2010).

The industrial applications of the Lobry de Bruyn-Alberda van Ekenstein rearrangement allow a maximum disaccharide yield of only $30 \%$ but the optimizations performed in a continuous flow process in the presence of complexing agents, enable the yield to achieve $88 \%$ (Schuster-Wolff-Bühring et al., 2010; Wang et al., 2017).

This reaction essentially transforms the aldehyde group of a reducing sugar into a ketone group, through enolization that is improved by high temperature. It is important to highlight that lactose must have high purity, since it has been used with lactulose as a starting material in the enzymatic synthesis (transgalactosylation reaction) of galacto-oligosaccharides using $\beta$ - galactosidade enzyme (Olano \& Corzo, 2009).

\subsection{Chemical method}

The technology to produce lactulose involves a reaction that isomerizes lactose in alkaline media. The first production of lactulose resulted from a mixture of of lactose and lime heated at $35^{\circ} \mathrm{C}$ (Montgomery \& Hudson, 1930). Then, the method used calcium hydroxide as catalyst for the isomerization reaction of lactose in lactulose: a solution with $60 \%$ lactose was blended with $0.1 \%$ of calcium hydroxide at $\sim 102{ }^{\circ} \mathrm{C}$ for 15 minutes and then a demineralization process using a combination of electrolysis and ion exchange resins (Matvievsky, 1979).
Besides calcium hydroxide, other catalysts that have been used are sodium hydroxide, potassium hydroxide, sodium carbonate (Harr \& Pluim, 1991; Deya \& Takahashi, 1991; Dendene et al., 1994; Zokaee et al., 2002), sodium sulfite (Gasparotti, 1981), sodium aluminate, magnesium oxide (Wang et al., 2017), boric acid (Hicks \& Parrish, 1980; Hicks et al., 1984), and organic alkaline reagents, such as tertiary amines (Parrish, 1970; Dendene et al., 1994; Zokaee et al., 2002). However, these catalysts provide low yields because some undesirable products are also formed during the process (Hicks \& Parrish, 1980; Mizota et al., 1987). Lactulose complexing reagents, e.g. sodium borate, minimize the secondary reactions, resulting in high yields of lactulose by shifting the equilibrium to favor lactulose formation, by its complexation with lactulose (Dendene et al., 1994; Zokaee et al., 2002).

\subsection{Enzymatic method}

The lactulose commercialized nowadays is synthesized by chemical processes. However, the bioproduction of lactulose using enzymes is a great alternative to minimize the disadvantages of chemical syntheses, such as degradation of lactulose and some by-products of complicated separation and purification. These factors increase the price and decrease the yield (Carobbi \& Innocenti, 1990; Zokaee et al., 2002; Silvério et al., 2016).

The enzymatic synthesis of lactulose is usually performed with $\beta$-galactosidase and glucosidase enzyme classes (Adamczak et al., 2009; Mayer et al., 2010; Zimmer et al., 2017). $\beta$-galactosidase is a biocatalyst used in the transgalactosylation reaction which may bioconvert lactose and fructose in lactulose (Panesar \& Kumari, 2011; Tang et al., 2011). $\beta$-galactosidase can be obtained from many different sources, such as microorganisms, plants and animals. However, the properties differ significantly according to its origin. The enzymes from plants and animals have low commercial value but various $\beta$-galactosidase microorganisms are of technological interest. In addition, the microorganisms provide many advantages, such as easy handling, greater proliferation rate and high production yield when compared with other available sources of this enzyme. The free $\beta$-galactosidase, as well as the ones in form of whole cells, can be immobilized and used for the production of lactulose (Panesar \& Kumari, 2011).

\section{Quantification and purification of lactulose}

The quantification of lactulose has been preformed using high-performance liquid chromatography (HPLC), and refractive index (RI) detector. Some of the factors that propitiate the use of this technique are: high selectivity, efficiency, separation capacity and process speed.

HPLC technique has improved the chromatographic columns and carbohydrates detection systems, becoming the most used technique for the identification and quantification of these compounds nowadays. Concerning liquid chromatography techniques, HPLC-RI Is the most common method for identification and quantification of saccharides.

Chromatographic columns containing $\mathrm{NH}_{2}$ as ionic form use a mixture of acetonitrile and water as eluent (Chen et al., 2003; Adamczak et al., 2009; Saron, 2003; Wang et al., 2017). Columns containing $\mathrm{Pb}^{2+}$ uses only ultrapure water as eluent 
(Acquaro et al., 2013; Zimmer et al., 2017). The analytes are retained by ion exchange between the hydroxyls of the oligosaccharides and ionic components of the column. Song et al. (2013) used in their study a high performance column for carbohydrates. They improved the lactulose synthesis from whey lactose with immobilized $\beta$-galactosidase enzyme. This column is specific to separate monosaccharides and disaccharides in a short time of analysis. Other types of chromatographic columns indicated for carbohydrates and sugars determination have not been found in the literature for lactulose identification.

HPLC allows monitoring the isomerization reaction of lactose into lactulose, determine the fractions collected from the chromatographic column with a predominance of lactulose (Figure 3 ) and verify the purity of these fractions and the yield (Saron, 2003).

HPLC-RI system is an economic method and it is used due to its precision and speed (Chávez-Servín et al., 2004). It was also used to determine sugar contents (glucose, fructose and sucrose) in apple juice (Garza et al., 1996), whey permeate disaccharides (lactose, galactose and lactulose), oligosaccharides (fructose, glucose, sucrose, maltose and lactose) in cereals, biscuits, fruits and canned vegetables. This method is also applied in the determination of sucrose, glucose and fructose in fruits and beverages samples (Casterline et al., 1999). Another alternative to
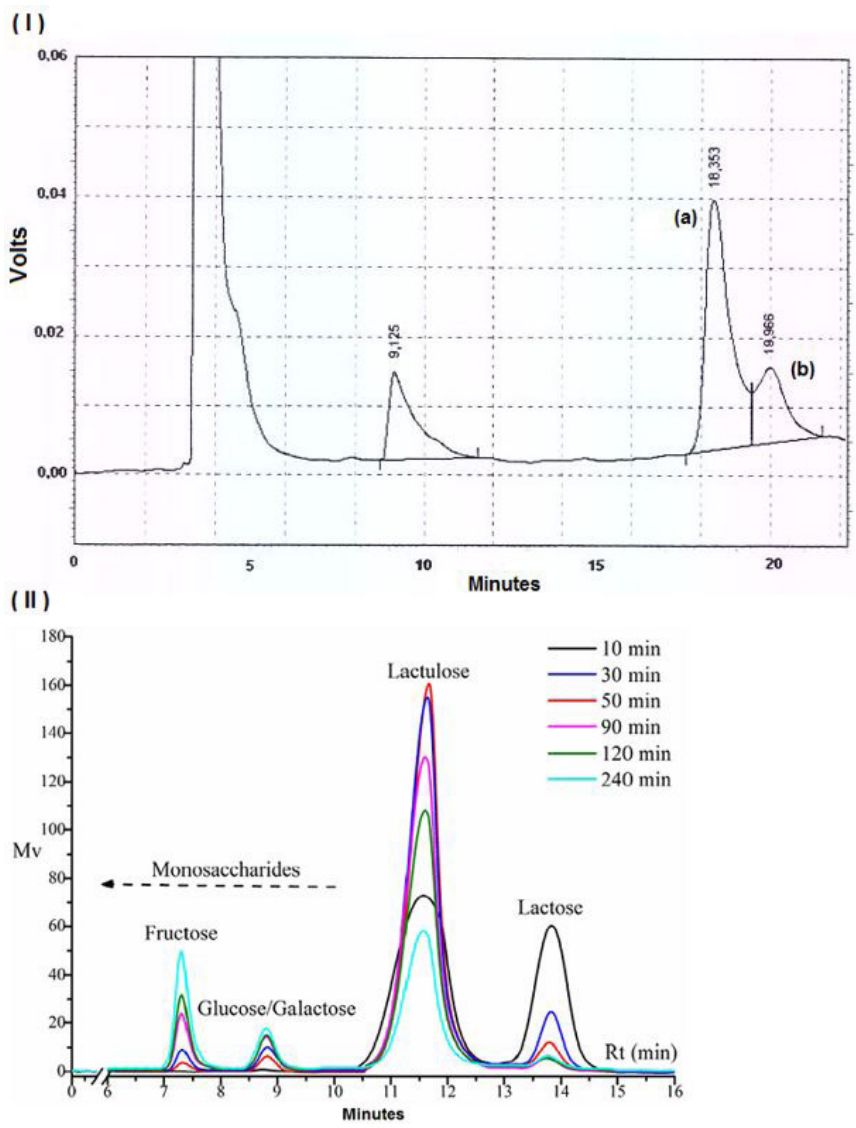

Figure 3. (I) Isomerization of whey permeate, (a) lactulose, (b) lactose, using chromatographic column containing $\mathrm{NH}_{2}$ (adapted, Saron, 2003) and (II) isomerizers sodium sulfite and sodium aluminate (Wang et al., 2017). the Refractive Index detector is the HPLC-ELSD-LT (ELSD-LT: Low Temperature Evaporative Light Scattering Detector), described by Schmidt et al. (2017). In this study, the ELSD conditions were optimized to detect low levels of lactulose without increasing too much baseline noise. Kubica et al. (2012) used HPLC-MS/MS (MS: Mass Spectrometry) to determine lactulose in human urine for studies involving intestinal permeability and upper digestive tract. In addition, Mass Spectrometry detector was also used as a comparative to other techniques in analyses for determination of lactulose and residual lactose in lactose-free milk samples by Trani et al. (2017).

Therefore, it is possible to use high performance liquid chromatography to monitor the isomerization reaction of lactose in lactulose, and to calculate the reaction yield. Saron (2003) achieved yields values around 70\% in alkaline medium. Considering the enzymatic isomerization, the highest degree of hydrolysis was 76\% according to Adamczak et al. (2009), and $55.59 \%$ according to Zimmer et al. (2017).

During the production of lactulose, the reaction mixture presents typically significant amounts of different components: lactose, glucose, galactose, and some traces of tagatose, epilactose and formic acid resulted from the degradation reaction (Schuster-Wolff-Bühring et al., 2010).

However, thermal analysis techniques associated to other techniques showed great results and were considered efficient to characterize several substances. The main advantages of these techniques are analysis speed, low operating cost and sample preparation simplicity. Bisinella et al. (2017) showed important information about lactulose behavior in their study. They performed the characterization of it using some analyses such as TG/DTG (Thermogravimetry / Derived Thermogravimetry), DSC- Thermomicroscopy (Differential Scanning Calorimetry coupled to Microscopy), used to determine thermal decomposition, kinetic parameters and purity. FTIR (Infrared Spectroscopy) and DRX (X-ray Diffraction) enabled the characterization of functional groups and the establishment the principal crystallinity peaks for lactulose, respectively.

The lactose degradation is reduced with lower $\mathrm{pH}$ and temperature of the obtained mixture. Thereafter, a separation process is applied to the lactulose, lactose and remaining catalysts. The lactose is crystallized and then recycled. The recovery of lactulose during processing is a crucial stage because the amount of lactulose is affected by both physical and chemical treatments. According to Ruiz-Matute et al. (2007), lactulose can be removed from mixture by extraction process using pressurized liquid at 1500 psi for 30 minutes; and the recovery of lactulose reached up to $84.4 \%$ with a purity of over $90 \%$. Nooshkam \& Madadlou (2016) modified the method for purification of lactulose proposed by Montañés et al. (2009), using carbon dioxide and ethanol/water as co-solvent. The isomerisate was purified by a simple, easily executable and economical procedure, which was compared to commercial lactulose syrups, with lactulose contents of $70 \%$.

\section{Conclusion}

Whey production has become one of the most critical issues for the dairy industry due to the increasing production of cheese and a more strict control of effluents disposal. Ultrafiltration allows the reuse of whey to obtain whey protein concentrate, 
a highly valued product in the food industry. This process generates another co-product, the whey permeate, which is rich in lactose. An alternative for its reuse is the process of chemical or enzymatic isomerization of lactose in lactulose. This product is considered a functional nutrient with great added value in the market because its is a synthetic prebiotic disaccharide with a large number of applications in food and pharmaceutical industries. The enzymatic method for isomerization of lactose in lactulose as an alternative of complete reuse of whey is simple and it does not produce by-products. Therefore, this process dispenses purification process, which is an advantage when compared to chemical method. The methodology for identification and quantification of isomerized products using HPLC-RI system was considered the most used for this type of sample matrix. It is economic, accurate and fast, and thermal analyses showed efficiency to characterize lactulose. Thus, this study proved that the disposal of industrial by-products can be reduced, and the nutritional quality of industrialized foods offered for population can be improved.

\section{Acknowledgements}

This research project was supported by CNPq (Conselho Nacional de Desenvolvimento Científico e Tecnológico) under project number 460761/2014-5 (call/public notice: MCTI/CNPQ/Universal 14/2014 - Faixa A).

\section{References}

Acquaro, V. R. Jr., Madeira, T. B., Castilho, D. C., Watanabe, L. S., Bovolenta, Y. R., \& Nixdorf, S. L. (2013). Desenvolvimento e validação de método para extração e quantificação através de HPLC com índice de refração para lactose em leite pasteurizado. Scientia Chromatographica, 5(2), 137-145. http://dx.doi.org/10.4322/ sc.2013.010.

Adamczak, M., Charubin, D., \& Bednarski, W. (2009). Influence of reaction medium composition on enzymatic synthesis of galactooligosaccharides and lactulose from lactose concentrates prepared whey permeate. Chemical Papers, 63(2), 111-116. http:// dx.doi.org/10.2478/s11696-009-0010-1.

Aider, M., \& Halleux, D. (2007). Isomerization of lactose and lactulose production. Food Science and Technology, 18(2), 356-364. Review. http://dx.doi.org/10.1016/j.tifs.2007.03.005.

Andrade, R. L. P., \& Martins, J. F. P. (2002). Influência da adição da fécula de batata-doce (Ipomoea batatas $L$.) sobre a viscosidade do permeado de soro de queijo. Ciência e Tecnologia de Alimentos, Campinas, 22(3), 249-253. http://dx.doi.org/10.1590/S0101-20612002000300009.

Atra, R., Vatai, G., Bekassy-Molnar, E., \& Balint, A. (2005). Investigation of ultra and nanofiltration for utilization of whey protein and lactose. Journal of Food Engineering, 67(3), 325-352. http://dx.doi. org/10.1016/j.jfoodeng.2004.04.035.

Baldasso, C., Barros, T. C., \& Tessaro, I. C. (2011). Concentration and purification of whey proteins by ultrafiltration. Desalination, 278(1-3), 381-386. http://dx.doi.org/10.1016/j.desal.2011.05.055.

Bisinella, R. Z. B., Ribeiro, J. C. B., Oliveira, C. S., Colman, T. A. D., Schnitzler, E., \& Masson, M. L. (2017). Some instrumental methods applied in food chemistry to characterise lactulose and lactobionic acid. Food Chemistry, 220, 295-298. PMid:27855902. http://dx.doi. org/10.1016/j.foodchem.2016.10.018.
Botega, L. M. G., Ramos, E. M., Dutra, M. P., Teixeira, J. T., Ramos, A. L. S., \& Contado, J. L. (2009). Avaliação da cor objetiva de apresuntados elaborados com diferentes concentrações de soro de leite. Higiene Alimentar, 23(170-171), 499-500.

Carobbi, R., \& Innocenti, F. (1990). European Patent No. 0320670: process for preparing lactulose from lactose by epimerization with sodium aluminate. Milano: Inalco Pharmaceuticals.

Casterline, J. L., Oles, C. J., \& Ku, Y. (1999). In vitro fermentation of various food fiber reactions. Journal of Agricultural and Food Chemistry, 45(7), 2463-2467. http://dx.doi.org/10.1021/jf960846f.

Chávez-Servín, J. L., Castellote, A. I., \& López-Sabater, M. C. (2004). Analysis of mono- and disaccharides in milk-based formulae by highperformance liquid chromatography with refractive index detection. Journal of Chromatography. A, 1043(2), 211-215. PMid:15330094. http://dx.doi.org/10.1016/j.chroma.2004.06.002.

Chen, C. W., Ou-Yang, C. C., \& Yeh, C. W. (2003). Synthesis of galactooligosaccharides and transgalactosylation modeling in reverse micelles. Enzyme and Microbial Technology, 33(4), 497-507. http:// dx.doi.org/10.1016/S0141-0229(03)00155-8.

Dendene, K., Guihard, L., Nicolas, S., \& Bariou, B. (1994). Kinetics of lactose isomerization of lactulose in an alkaline medium. Journal Chemistry. Technology and Biotechonology, 61(1), 37-42.

Deya, E., \& Takahashi, K. (1991). U.S. Patent No. 5034064: production process of high purity lactulose syrup. Tokio: Snow Brand Milk Products Co. Ltd.

Erkkila, A. T., Sarkkinen, E. S., Lehto, S., Pyörälä, K., \& Uusitupa, M. I. J. (1999). Dietary associates of serum total, LDL, and HDL cholesterol and triglycerides in patients with coronary heart disease. Preventive Medicine, 28(6), 558-565. PMid:10404553. http://dx.doi. org/10.1006/pmed.1998.0478.

Fennema, O. R., Damodaran, S., \& Parkin, K. L. (2010). Química de alimentos de Fennema. 4th ed. Porto Alegre: Artmed.

Fox, P. F., \& McSweeney, P. (1998). Lactose, water, salts and minor constituents: advanced dairy chemistry. 1th ed. Londres: Champman \& Hall.

Gänzle, M. G., Haase, G., \& Jelen, P. (2008). Lactose: crystallization, hydrolysis and value-added derivatives. International Dairy Journal, 18(7), 685-694. http://dx.doi.org/10.1016/j.idairyj.2008.03.003.

Garza, S., Giner, J., Martín, O., Costa, E., \& Ibarz, A. (1996). Evolución del color, azúcares y HMF en el tratamiento térmico de zumo de manzana/Colour, sugars and HMF evolution during thermal treatment of apple juice. Food Science \& Technology International, 2(2), 101-110. http://dx.doi.org/10.1177/108201329600200207.

Gasparotti, F. A. (1981). U.S. Patent No. 4, 264, 763: process for producin lactulose. Florence, Italy. U.S Patent and Trademark Office.

Harr, W. T., \& Pluim, H. (1991). European Patent No. 0339749: method of preparing lactulose. Munich: European Patent Office.

Hicks, K. B., \& Parrish, F. W. (1980). A new method for the preparation of lactulose from lactose. Carbohydrate Research, 82(2), 393-397. http://dx.doi.org/10.1016/S0008-6215(00)85716-X.

Hicks, K., Raupp, D., \& Smith, W. (1984). Preparations and purification of lactulose from sweet cheese whey ultrafiltrate. Journal of Agricultural and Food Chemistry, 32(2), 288-292. http://dx.doi.org/10.1021/ jf00122a028.

Kubica, P., Kot-Wasik, A., Wasik, A., Namiésnik, J., \& Landowski, P. (2012). Modern approach for determination of lactulose, mannitol and sucrose in human urine using HPLC-MS/MS for the studies of intestinal and upper digestive tract permeability. Journal of Chromatography. B, Analytical Technologies in the Biomedical and 
Life Sciences, 907, 34-40. PMid:22985725. http://dx.doi.org/10.1016/j. jchromb.2012.08.031.

Matvievsky, V. Y. (1979). Investigation of process for lactose/lactulose syrup production for infantile food (Master thesis). Uglich Institute, Washington.

Mayer, J., Kranz, B., \& Fischer, L. (2010). Continuous production of lactulose by immobilized thermostable $\beta$-glycosidase from Pyrococcus furiosus. Journal of Biotechnology, 145(4), 387-393. PMid:20036700. http://dx.doi.org/10.1016/j.jbiotec.2009.12.017.

Mizota, T., Tamura, Y., Tomita, M., \& Okonogi, S. (1987). Lactulose as a sugar with phisiological significance. Bulletin of the International Dairy Federation, 212, 69-76.

Modler, H. W., McKellar, R. C., \& Yaguchi, M. (1990). Bifidobacteria and bifidogenic factors. Canadian Institute of Food Science and Technology Journal, 23(1), 29-41. http://dx.doi.org/10.1016/S03155463(90)70197-6.

Montañés, F., Fornari, T., Stateva, R. P., Olano, A., \& Ibáñez, A. (2009). Solubility of carbohydrates in supercritical carbon dioxide with (ethanol + water) cosolvent. The Journal of Supercritical Fluids, 49(1), 16-22. http://dx.doi.org/10.1016/j.supflu.2008.11.014.

Montgomery, E. M., \& Hudson, C. S. (1930). Relations between rotating power and structure in the sugar group. Synthesis of new disaccharide ketoses from lactose. Journal of the American Chemical Society, 52(5), 2101-2111. http://dx.doi.org/10.1021/ja01368a060.

Nath, A., Veraszto, B., Basak, S., Koris, A., Kovacs, Z., \& Vatai, G. (2016). Synthesis of lactose-derived nutraceuticals from dairy waste whey-a review. Food and Bioprocess Technology, 9(1), 16-48. http://dx.doi. org/10.1007/s11947-015-1572-2.

Nooshkam, M., \& Madadlou, A. (2016). Microwave-assisted isomerisation of lactose to lactulose and Maillard conjugation of lactulose and lactose with whey proteins and peptides. Food Chemistry, 200, 1-9. PMid:26830553. http://dx.doi.org/10.1016/j.foodchem.2015.12.094.

Okara, A. I., Aleshkov, A. V., \& Kalenik, T. K. (2010). Meat containing semi-products enriched in lactulose. Meat Industry, 10(1), 53-56.

Olano, A., \& Corzo, N. (2009). Lactulose as a food ingredient. Journal of the Science of Food and Agriculture, 89(12), 1987-1990. http:// dx.doi.org/10.1002/jsfa.3694.

Oliveira, M. N. (2009). Tecnologia de produtos lácteos funcionais. São Paulo: Atheneu.

Ordoñez, J. A. (2005). Tecnologia de alimentos. componente dos alimentos e processos. São Paulo: Artmed.

Panesar, P. S., \& Kumari, S. (2011). Lactulose: production, purification and potential applications. Biotechnology Advances, 29(6), 940-948. PMid:21856402. http://dx.doi.org/10.1016/j.biotechadv.2011.08.008.

Parrish, F. W. (1970). U.S. Patent No. 3514327: isomerization of glucose, maltose, and lactose with amino compounds. United States: Us Army.

Pelegrine, D. H. G., \& Carrasqueira, R. L. (2008). Whey uses in nutritional beverages enrichment. Brazilian Journal of Food Technology, 18(36), 145-151. http://dx.doi.org/10.15600/2238-1252/rct.v18n36p3-11.

Pereira, J. P. F., Perrone, Í. T., Machado, G. D. M., Renhe, I. R. T., \& Pereira, D. B. C. (2010). Percentage of lactose crystallization in whey concentrate by lab-scale crystallizer. Journal of Candido Tostes Dairy Institute, 65(374), 26-32.

Perrone, Í. T., Pereira, J. P. F., \& Carvalho, A. F. (2011). Technological aspects of whey powder manufacturing: a review. Journal of Candido Tostes Dairy Institute, 380(66), 23-30.

Philippi, S. T. (2008). Pirâmide dos alimentos: fundamentos básicos da nutrição. Barueri: Manole.
Ramos, E. M., \& Gomide, L. A. M. (2007). Avaliação da qualidade de carnes: fundamentos e metodologias. Viçosa: Editora UFV.

Roberfroid, M. (2002). Functional food concept and its application to prebiotics. Digestive and Liver Disease, 34(2, Suppl 2), 105-110. PMid:12408452. http://dx.doi.org/10.1016/S1590-8658(02)80176-1.

Ruiz-Matute, A. I., Sanz, M. L., Corzo, N., Martín-Álvarez, P. J., Ibáñez, E., Martínez-Castro, I., \& Olano, A. (2007). Purification of lactulose from mixtures with lactose using pressurized liquid extraction with ethanol-water at different temperatures. Journal of Agricultural and Food Chemistry, 55(9), 3346-3350. PMid:17394342. http://dx.doi. org/10.1021/jf070018u.

Saron, M. L. G. (2003). Aproveitamento do permeado de soro de leite bovino através da transformação da lactose em lactulose e como ingrediente para meios de culturas de bactérias probióticas (Dissertação de mestrado). Universidade Estadual de Campinas, Campinas.

Schmidt, C. M., Zurn, T., Thienel, K. J. F., \& Hinrichs, J. (2017). Development, optimization and validation of an HPLC-ELSD method for the analysis of enzymatically generated lactulose and saccharide by-products. Food Chemistry, 215, 347-353. PMid:27542485. http:// dx.doi.org/10.1016/j.foodchem.2016.07.184.

Schuster-Wolff-Bühring, R., Fischer, L., \& Hinrichs, J. (2010). Production and physiological action of the disaccharide lactulose. International Dairy Journal, 20(11), 731-741. http://dx.doi.org/10.1016/j. idairyj.2010.05.004.

Seki, N., \& Saito, H. (2012). Lactose as a source for lactulose and other functional lactose derivatives. International Dairy Journal, 22(2), 110-115. http://dx.doi.org/10.1016/j.idairyj.2011.09.016.

Silva, L. L., \& Stamford, T. L. M. (2000). Alimentos probióticos: uma revisão. Higiene Alimentar, 14(68-69), 41-50.

Silvério, S. C., Macedo, E. A., Teixeira, J. A., \& Rodrigues, L. R. (2016). Biocatalytic approaches using lactulose: end product compared with substrate. Comprehensive Reviews in Food Science and Food Safety, 15(5), 878-896. http://dx.doi.org/10.1111/1541-4337.12215.

Song, Y. S., Lee, H.-U., Park, C., \& Kim, S.-W. (2013). Optimization of lactulose synthesis from whey lactose by immobilized $\beta$-galactosidase and glucose isomerase. Carbohydrate Research, 369, 1-5. PMid:23353997. http://dx.doi.org/10.1016/j.carres.2013.01.002.

Tamura, Y., Mizota, T., Shimamura, S., \& Tomita, M. (1993). Lactulose and its application to the food and pharmaceutical industries. Bulletin of the International Dairy Federation, 289, 43-53.

Tang, L., Li, Z., Dong, X., Yang, R., Zhang, J., \& Mao, Z. (2011). Lactulose biosynthesis by $\beta$-galactosidase from a newly isolated Arthrobacter sp. Journal of Industrial Microbiology \& Biotechnology, 38(3), 471476. PMid:21104424. http://dx.doi.org/10.1007/s10295-010-0897-0.

Trani, A., Gambacorta, G., Loizzo, P., Cassone, A., Fasciano, C., Zambrini, A. P., \& Faccia, M. (2017). Comparison of HPLC-RI, LC/MS-MS and enzymatic assays for the analysis of residual lactose in lactose-free milk. Food Chemistry, 233, 385-390. PMid:28530589. http://dx.doi. org/10.1016/j.foodchem.2017.04.134.

Wang, M., Gasmalla, M. A. A., Admassu Tessema, H., Hua, X., \& Yang, R. (2017). Lactulose production from efficient isomerization of lactose catalyzed by recyclable sodium aluminate. Food Chemistry, 233, 151-158. PMid:28530560. http://dx.doi.org/10.1016/j. foodchem.2017.04.080.

Yee, K. W. K., Wiley, D. E., \& Bao, J. (2007). Whey protein concentrate production by continuous ultrafiltration: operability under constant operating conditions. Journal of Membrane Science, 290(2), 125-137. http://dx.doi.org/10.1016/j.memsci.2006.12.026.

Yorgun, M. S., Balcioglu, A., \& Saygin, O. (2008). Performance comparison os ultrafiltration, nanofiltration and reverse osmosis 
on whey treatment. Desalination, 229(1-3), 204-216. http://dx.doi. org/10.1016/j.desal.2007.09.008

Zhang, W., Xiao, S., Samaraweera, H., Lee, E. J., \& Ahn, D. U. (2010). Improving functional value of meat products. Meat Science, 86(1), 1531. PMid:20537806. http://dx.doi.org/10.1016/j.meatsci.2010.04.018.

Ziegler, F. L. F., \& Sgarbieri, V. C. (2009). Chemical-nutritional characterization of a whey protein isolate a bovine collagen hydrolysate and mixtures of the two products. British Journal of Nutrition, 22(1), 61-70.
Zimmer, F. C., Souza, A. H. P., Silveira, A. F. C., Santos, M. R., Matsushita, M., Souza, N. E., \& Rodrigues, A. C. (2017). Application of Factorial Design for Optimization of the Synthesis of Lactulose Obtained from Whey Permeate. Journal of the Brazilian Chemical Society http://dx.doi.org/10.21577/0103-5053.20170083.

Zokaee, F., Kaghazchi, T., Zare, A., \& Soleimani, M. (2002). Isomerization of lactose to lactulose - study and comparision of three catalytic systems. Process Biochemistry, 37(6), 629-635. http://dx.doi. org/10.1016/S0032-9592(01)00251-5. 